Vol. 1 | No. 4 | Oktober 2020 | Hal. 280 - 285

\title{
PEMANFAATAN TANAMAN PAITAN YANG BERLIMPAH SEBAGAI POC (PUPUK ORGANIK CAIR) GUNA MENDUKUNG PERTANIAN RAMAH LINGKUNGAN
}

\author{
Anis Sholihah, Muchtar Abdul Latif, Rizaldi Al Ayubi, Diana Yusuf Adi Prasetyo, \\ Herdian Irwansyah, Ida Uswatun Hasanah, Rifdha Hasna' Rohadatul Aisy, Nindya \\ Febri Setyo Utami, Maesaroh, Addelia Shakila, Zuhanid Zamarudah, Dhea Alief \\ Rahmasari \\ Fakultas Pertanian, Universitas Islam Malang
}

Korespondensi email: anis.sholihah@unisma.ac.id

\begin{abstract}
ABSTRAK
POC (pupuk organik cair) adalah pupuk yang tersedia dalam bentuk cair dan dibuat secara alami melalui proses fermentasi sehingga menghasilkan larutan hasil pembusukan dari sisa tanaman, maupun kotoran hewan atau manusia. Teknologi pembuatan POC sendiri kurang dikuasai petani, sehingga kelompok KKN 46 berinisiatif perlu melakukan pelatihan pembuatan POC bagi petani di Desa Glanggang Kecamatan Pakisaji Kabupaten Malang dengan memanfaatkan tanaman paitan. Tanaman paitan sendiri di desa Glanggang dianggap gulma oleh masyarakat setempat yang tumbuh liar dan berlimpah di desa tersebut. Disamping memanfaatkan tanaman liar tujuan dari pembuatan POC ini adalah untuk mengurangi kebiasaan petani desa Glanggang dalam penggunaan pupuk kimia ke pupuk organik cair ramah lingkungan. Pelaksanaan kegiatan terdiri dari beberapa tahapan; tahap pertama yaitu survey lokasi tanaman paitan yang tumbuh liar dan berlimpah, tahap kedua berkoordinasi dengan ketua kelompok tani "Dewi Sri" di desa Glanggang, tahap ketiga persiapan pelaksanaan pelatihan dan tahap terakhir yaitu tahap keempat adalah pelaksanaan kegiatan pembuatan POC.
\end{abstract}

Kata Kunci: poc; tanaman paitan.

\section{PENDAHULUAN}

Program kuliah kerja nyata (KKN) tematik merupakan program Universitas Islam Malang sebagai salah satu implementasi Tri Dharma Perguruan Tinggi yaitu pengabdian mahasiswa terhadap masyarakat. Program ini diharapkan dapat membantu dan membimbing masyarakat dalam memanfaatkan potensi sumberdaya setempat. Selain itu program ini juga diharapkan dapat menjadi sarana untuk membantu mahasiswa dalam mengaplikasikan ilmu pengetahuan secara nyata sehingga dapat memberikan nilai dan manfaat bagi masyarakat khususnya di bidang pertanian.

Salah satu desa yang memiliki potensi di bidang pertanian yaitu Desa Glanggang yang berada di Kecamatan Pakisaji Kabupaten Malang. Luas lahan pertanian di desa ini sekitar 150,33 ha yang terdiri dari komoditas padi dan jagung dengan jenis tanah berwarna hitam, tekstur tanah berlempung dan tingkat kemiringan tanah sebesar $3 \circ$, dengan kondisi geografis yang sesuai, sebagian besar masyarakat desa ini bekerja sebagai petani. Petani di desa Glanggang sangat tergantung pada pupuk kimia yang pastinya akan berdampak menurunkan kesuburan tanah baik secara fisik, kimia dan biologi tanah, sehingga perlu ada usaha-usaha untuk mengurangi ketergantungan terhadap pupuk kimia salah satunya dengan penggunaan POC. 
KKN-PPM UNISMA edisi Covid-19 kelompokn 46 mengadakan program kerja bersama kelompok tani "Dewi Sri” Desa Glanggang untuk membuat pupuok organik cair (POC) yang berbahan dasar paitan. Hal ini dikarenakan keberadaan daun paitan di desa ini masih banyak tersedia. Selain itu, daun paitan juga berfungsi sebagai insektisida alami.

Menurut Moenandir (2010) bahwa tanaman paitan digolongkan dalam tanaman gulma, namun tanaman ini berkhasiat untuk menyuburkan tanaman tanaman karena cepat terdekomposisi, dapat menyediakan nutrisi bagi tanaman dan kaya akan pospor. Menurut Susanti, Widyastuti, \& Sulistyo (2015) hasil pengujian dari beberapa tumbuhan penghasil peptisida dan nabati, daun tanaman paitan yang yang diujikan terhadap Tribolium castaneum merupakan jenis pestisida penolak.

Pupuk terbagi atas dua jenis pupuk, yaitu pupuk organik dan pupuk anorganik. Kelemahan pupuk anorganik jika pemberiannya diberikan secara terus menerus atau berlebih akan berdampak buruk pada tanah, tanaman maupun lingkungan. Suyamto (2017) menyebutkan bahwa penggunaan pupuk anorganik secara terus menerus menjadi tidak efisien dan dapat mengganggu keseimbangan sifat tanah baik secara fisik, kimia dan biologi sehingga menurunkan produktivitas lahan, mempengaruhi produksi tanaman sertameninggalkan residu yang dapat merusak lingkungan oleh karena itu dalam usaha pertanian saat ini lebih dianjurkan pemberian pupuk anorganik diimbangi dengan penggunaan pupuk organic (Kresnatita, Koesriharti, \& Santoso, 2013; Susilowati \& Mardiyani, 2019).

Di kalangan petani, kebergantungan dalam menggunakan pupuk kimia sintetis hampir mencapai $98 \%$, sedangkan penggunaan pupuk organik masih kurang. Pemberian pupuk kimia sintetis bukanlah jaminan untuk memperoleh hasil maksimal tanpa diimbangi pupuk organik karena pupuk organik mampu berperan terhadap perbaikan sifat fisik, kimia, dan biologi tanah (A. Marpaung, Karo, \& Tarigan, 2016). Hal ini didukung oleh Fikri, Marsudi, \& Jati (2014) bahwa penggunaan dosis pupuk kimia sintetis yang berlebihan dapat menyebabkan pencemaran lingkungan, apalagi penggunaan secara terus menerus dalam waktu lama dapat menyebabkan produktivitas lahan menurun dan mikroorganisme penyubur tanah berkurang. Herdiyanto \& Setiawan (2015) menambahkan bahwa penggunaan pupuk sintetis yang tinggi pada tanah dapat mendorong hilangnya hara, polusi lingkungan, dan rusaknya kondisi alam.

Penggunaan pupuk organik alam yang dapat dipergunakan untuk membantu mengatasi kendala produksi pertanian yaitu pupuk organik cair. Pupuk organik cair merupakan salah satu jenis pupuk yang banyak beredar di pasaran (Sholihah \& Nurhidayati, 2018). Pupuk organik cair kebanyakan diaplikasikan melalui daun atau disebut sebagai pupuk cair daun yang mengandung hara makro dan mikro esensial (Wenda, Hidayati, \& Purwanti, 2017). Pupuk organik cair mempunyai beberapa manfaat di antaranya dapat mendorong dan meningkatkan pembentukan klorofil daun dan pembentukan bintil akar pada tanaman leguminosae, sehingga meningkatkan kemampuan fotosintesis tanaman dan penyerapan nitrogen dariudara, dapat meningkatkan vigor tanaman, sehingga tanaman menjadi kokoh dan kuat, meningkatkan daya tahan tanaman terhadap kekeringan, cekaman cuaca, dan serangan pathogen penyebab penyakit, merangsang pertumbuhan cabang produksi, serta meningkatkan pembentukan bunga dan bakal buah,serta mengurangi gugurnya daun, bunga, dan bakal buah (A. E. Marpaung, 2017; Mappanganro, Kiramang, \& Kurniawan, 2019).

\section{METODE}

Pelaksanaan kegiatan pembuatan pupuk POC dilakukan dengan 4 tahapan yaitu:

\section{Tahap Pertama Survey Lokasi Tanaman Paitan}


Tahap pertama melakukan survey di desa Glanggang dengan tujuan mendapatkan informasi lokasi-lokasi yang berlimpah tanaman paitan sehingga akan memudahkan kita mendapatkan bahan utama untuk pembuatan POC.

\section{Tahap Kedua Koordinasi dengan Ketua Kelompok Tani “Dewi Sri”}

Pelaksanaan pelatihan pembuatan POC bekerjasama dengan kelompok tani "Dewi Sri" di desa Glanggang dimana pada tahap ini melakukan koordinasi dengan ketua kelompok dan pengurusnya untuk menentukan waktu yang tepat pelaksanaan kegiatan pelatihan pembuatan POC dan menghasilkan kesepakatan pada tanggal 5 Agustus 2020.

3. Tahap Ketiga Persiapan Pelaksanaan Pelatihan

Pada tahap ini dilakukan persiapan alat dan bahan yang diperlukan untuk pelaksanaan pelatihan pembuatan POC pada tanggal 5 Agustus 2020. Alat-alat yang dipersiapkan meliputi; tong, pisau, telenan, botol, tabung ukur, pengaduk, timbangan dan gunting. Bahan yang dipersiapkan meliputi; daun paitan, gula, EM4 dan air.

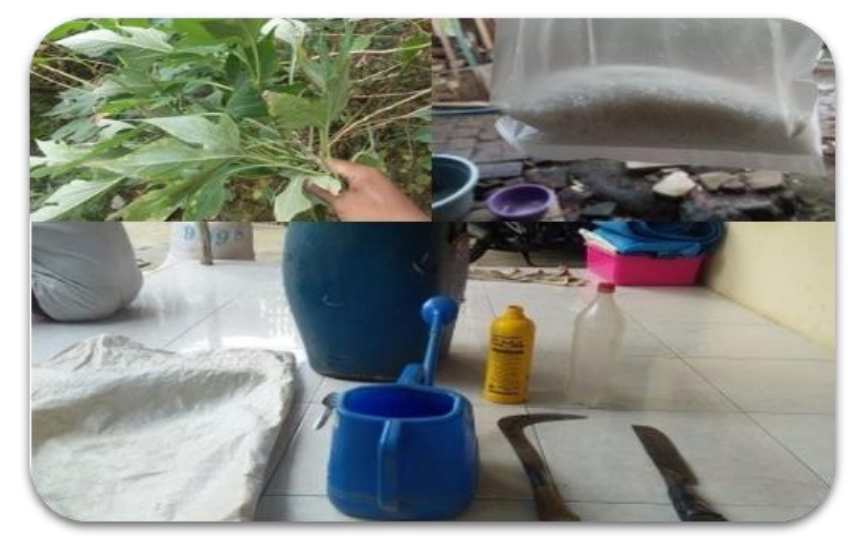

Gambar 1. Alat \& Bahan

\section{Tahap Keempat Pelaksanaan Pelatihan Pembuatan POC}

Pelaksanaan pelatihan pembuatan POC diikuti oleh 20 petani dari kelompok tani "Dewi Sri". Bertempat di Balai Desa pelaksanaan diawali dengan penyuluhan selanjutnya diteruskan dengan praktek langsung pembuatan POC. Langkah kerja pembuaatan POC sebagai berikut:

- Mencacah daun paitan

- Menimbang daun paitan sebanyak 2,5 kg untuk masing-masing tong

- Menambahkan air ke dalam tong sebanyak 25 liter

- Mengukur EM4 ke gelas ukur sebanyak 1/2 liter

- Menimbang gula sebanyak 5 sendok makan

- Menambahkan EM4 dan gula ke dalam larutan dalam tong

- Menutup tong dengan rapat agar tidak ada udara yang masuk

- Melakukan proses fermentasi selama 3 minggu pada larutan pupuk organik cair, agar mikroba pada larutan dapat menguraikan daun paitan dengan baik.

- Setelah melakukan proses fermentasi, memindahkan pupuk organik cair yang telah jadi ke dalam botol berukuran 1 liter.

- Memberi label pada botol.

\section{HASIL DAN PEMBAHASAN}

Hasil pelaksanaan dari kegiatan ini yaitu berupa pupuk organic cair (POC) yang berbahan dasar daun paitan, disamping itu adanya tekonologi baru tentang pembuatan POC 
bagi petani di desa Glanggang memanfaatkan tanaman paitan yang banyak di sekitar daerah mereka. Dengan adanya program kerja ini tanaman yang dianggap tidak memiliki nilai guna dapat dimanfaatkan oleh petani sebagai bahan baku pembuatan pupuk organik dan mengurangi ketergantungan petani terhadap pupuk kimia, disamping itu 80 persen petani paham akan pentingnya pupuk organik dan kemampuan membuat POC.

POC (pupuk organik cair) adalah pupuk yang tersedia dalam bentuk cair, POC (pupuk organik cair) dapat diartikan sebagai pupuk yang dibuat secara alami melalui proses fermntasi sehingga menghasilkan larutan hasil pembusukan dari sisa tanaman, maupun kotoran hewan atau manusia. Bagi sebagian orang pupuk organik cair lebih baik untuk digunakan karna terhindar dari bahan-bahan kimia serta dampak yang tidak baik bagi kesehatan.

Salah satu contoh tanaman yang dapat digunakan sebagai bahan dasar POC yaitu daun paitan. Daun paitan memiliki manfaat di antaranya yaitu mendukung pertumbuhan dan produksi tanaman, mampu mengurangi polutan dan menurunkan tingkat jerap $\mathrm{P}, \mathrm{Al}$ dan Fe aktif, Meningkatkan bobot segar tanaman karena mudah terdekomposisi, menyediakan nitrogen dan unsur hara bagi tanaman, melepaskan unsur NPK tersedia dan meningkatkan unsur P pada tanah.

Ada 2 cara dalam mengaplikasikan pupuk organik cair, yaitu dengan cara menyiram ke media tanam dan menyemprotkan secara langsung ke bagian daun. Selain diserap lewat akar, penyiraman memiliki tujuan untuk menghancurkan sisa pupuk kimia dalam tanah sehingga tanah menjadi gembur kembali. Sedangkan penyemprotan bertujuan agar pupuk cepat masuk ke dalam tanaman melalui lubang stomata pada daun, sehingga dapat digunakan langsung oleh tanaman. Pemberian pupuk baik penyemprotan atau penyiraman, akan lebih baik jika semua dosis tidak langsung diberikan.

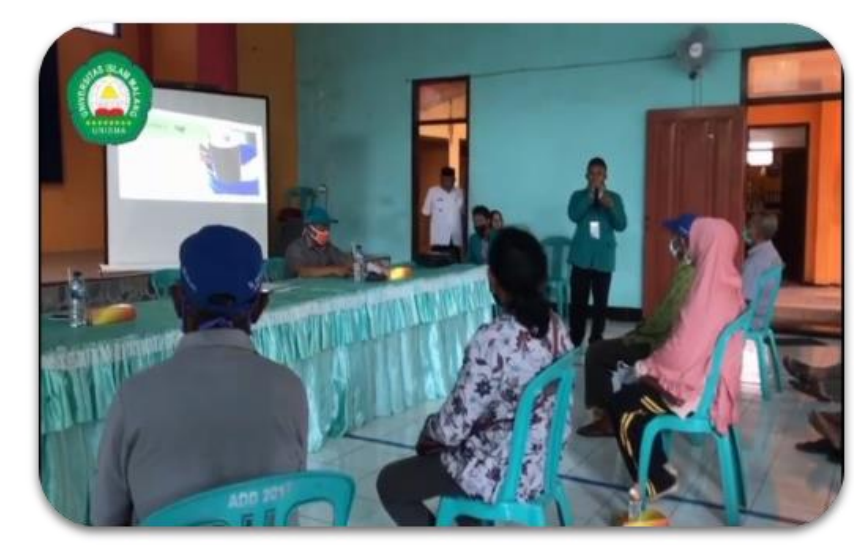

Gambar 2. Pelaksanaan Penyuluhan Manfaat POC

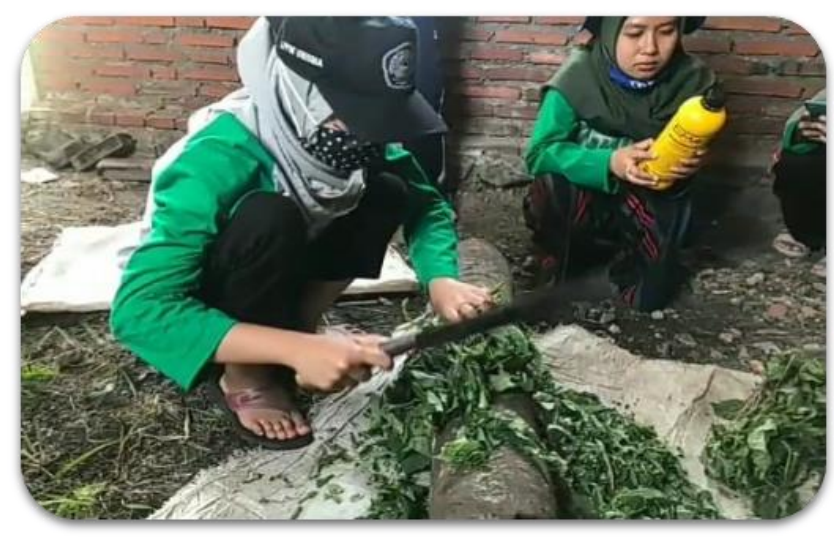

Gambar 3. Mencacah Daun Paitan 


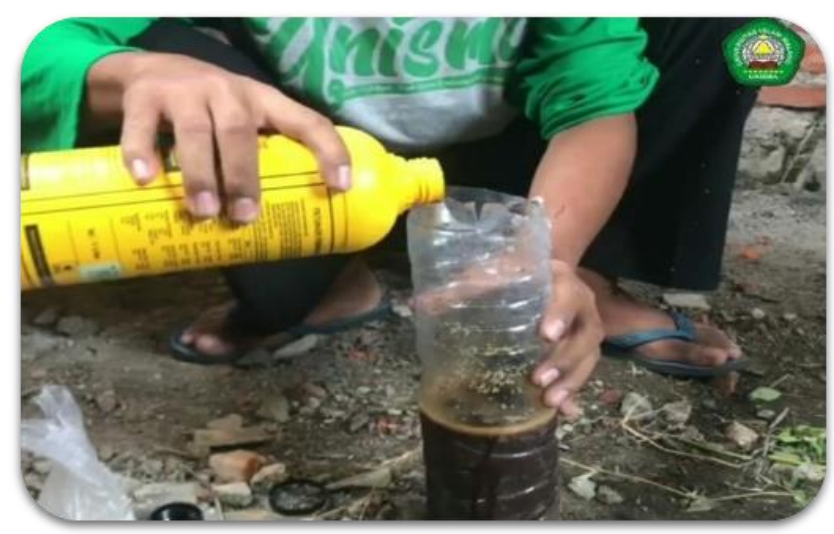

Gambar 4. Proses Penambahan EM4

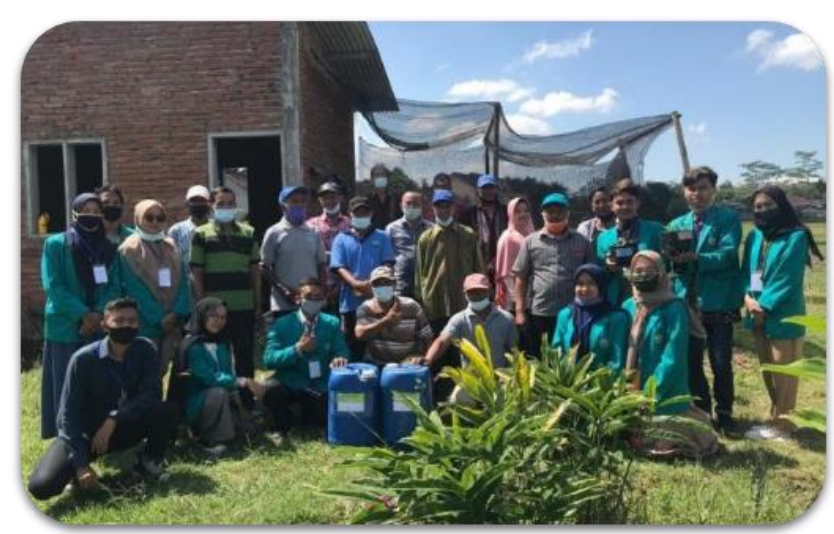

Gambar 5. Penyerahan hasil POC kepada kelompok tani "Dewi Sri”

\section{KESIMPULAN}

Dari kegiatan pelaksanakan penyuluhan pembuatan POC dari tanaman paitan dapat disimpulkan bahwa (1) Petani desa Glanggang yang tergabung dalam kelompok tani “ Dewi Sri " telah menguasai teknologi pembuatan pupuk organik cair (POC) dari tanaman paitan dan memahami pentingnya pupuk organik mencapai 80 persen, (2) Telah tersedia sarana dan prasarana untuk pembuatan pembuatan pupuk organik cair (POC) dari tanaman paitan; (3) Telah dihasilkan luaran video pembuatan pupuk organik cair (POC) dari tanaman paitan dan telah di upload di youtube dengan link (http://youtu.be/EHJUSe9NMjQ).

\section{UCAPAN TERIMA KASIH}

Ucapan terima kasih disampaikan kepada LPPM UNISMA yang memberikan kesempatan kepada kelompok 46 untuk melakukan kegiatan KKN di desa Glanggang, Kecamatan Pakisaji, Kabupaten Malang.

\section{DAFTAR RUJUKAN}

Fikri, U., Marsudi, \& Jati, D. R. (2014). Pengaruh Penggunaan Pupuk Terhadap Kualitas Air Tanah Di Lahan Pertanian Kawasan Rawa Rasau Jaya III, Kab. Kubu Raya. Jurnal Teknologi Lingkungan Lahan Basah, 2(1), 1-10. https://doi.org/10.26418/jtllb.v2i1.8280

Herdiyanto, D., \& Setiawan, A. (2015). Upaya peningkatan kualitas tanah melalui sosialisasi pupuk hayati, pupuk organik, dan olah tanah konservasi di Desa Sukamanah dan Desa Nanggerang Kecamatan Cigalontang Kabupaten Tasikmalaya. Dharmakarya: Jurnal Aplikasi Ipteks Untuk Masyarakat, 4(1), 47-53. 
https://doi.org/10.24198/dharmakarya.v4i2.10028

Kresnatita, S., Koesriharti, \& Santoso, M. (2013). HASIL TANAMAN JAGUNG MANIS Effects of Organic Manure on Growth and Yield of Sweetcorn. Indonesia Green Technology Journal, 2(1), 8-17. Retrieved from https://igtj.ub.ac.id/index.php/igtj/article/view/108

Mappanganro, R., Kiramang, K., \& Kurniawan, M. D. (2019). Pemberian Pupuk Organik Cair (Urin Sapi) terhadap Tinggi Pennisetum purpureum cv. Mott. Jurnal Ilmu Dan Industri Peternakan Uournal of Animal Husbandry Science and Industry), 4(1), 23. https://doi.org/10.24252/jiip.v4i1.9815

Marpaung, A. E. (2017). Pemanfaatan Jenis Dan Dosis Pupuk Organik Cair (POC) Untuk Meningkatkan Pertumbuhan Dan Hasil Sayuran Kubis. Jurnal Agroteknosains, 01(02), 117-123. https://doi.org/10.36764/ja.v1i2.39

Marpaung, A., Karo, B., \& Tarigan, R. (2016). Pemanfaatan Pupuk Organik Cair dan Teknik Penanaman Dalam Peningkatan Pertumbuhan dan Hasil Kentang. Jurnal Hortikultura, 24(1), 49-55. https://doi.org/10.21082/jhort.v24n1.2014.p49-55

Moenandir, J. (2010). Ilmu Gulma. (D. Y. Hersanjaya, Ed.). Malang: UB Press.

Sholihah, A., \& Nurhidayati. (2018). IbM KELOMPOK TANI HORTIKULTURA DALAM RANGKA PERBAIKAN MANAJEMEN PRODUKSI KOMPOS. Jurnal Inovasi Hasil $\begin{array}{lll}\text { Pengabdian } \quad \text { Masyarakat } & \text { (JIPEMAS), }\end{array}$ https://doi.org/10.33474/jipemas.v1i2.1513

Susanti, D., Widyastuti, R., \& Sulistyo, A. (2015). Aktifitas Anteefedant dan Antioviposisi Ekstrak Daun Thitonia Terhadap Kutu Kebul. Agrosains, 17(2), 33-38. https://doi.org/10.20961/agsjpa.v17i2.18666

Susilowati, D., \& Mardiyani, S. A. (2019). Pengayaan Nutrisi (fortifikasi) pada Olahan Singkong Berbasis Partisipatoris. Jurnal Inovasi Hasil Pengabdian Masyarakat (JIPEMAS), 2(2), 100-109. https://doi.org/10.33474/jipemas.v2i2.2687

Suyamto. (2017). Manfaat Bahan dan Pupuk Organik pada Tanaman Padi di Lahan Sawah Irigasi. Iptek Tanaman Pangan, 12(2), 67-74. Retrieved from http://ejurnal.litbang.pertanian.go.id/index.php/ippan/article/view/8179

Wenda, M., Hidayati, S., \& Purwanti, S. (2017). APLIKASI PUPUK ORGANIK CAIR DAN KOMPOSISI MEDIA TANAM TERHADAP HASIL TANAMAN SELADA (Lactuca sativa L). Gontor AGROTECH Science Journal, 3(2), 99-118. https://doi.org/10.21111/agrotech. 